\title{
Roles of the riparian vegetation: the antagonism between flooding risk and the protection of environments
}

\author{
Caroline Zanetti ${ }^{1, a}$, Julie Macia ${ }^{1}$, Nelly Liency ${ }^{1}$, Michel Vennetier ${ }^{2}$, Patrice Mériaux $^{3}$ and Mireille Provansal ${ }^{4}$ \\ ${ }^{1}$ ARBEAUSOLutions, Vegetation Expertise on dikes, 13590 Meyreuil, France \\ ${ }^{2}$ IRSTEA, Mediterranean Ecosystem and Risks, 13182 Aix en Provence Cedex 5, France \\ ${ }^{3}$ IRSTEA, Hydraulic structures and Hydrology, 13182 Aix en Provence Cedex 5, France \\ ${ }^{4}$ CEREGE, Geomorphology and Tectonic, 13545 Aix en Provence Cedex 4, France
}

\begin{abstract}
Since the beginning of the 20th century, man has domesticated his environment and caused the modification of hydraulic conditions during floods. In parallel, civil engineering has strongly progressed in the domain of hydraulic structures but especially the construction of dams and dikes has also massively increased and part of the population has lost the culture of risk by thinking they were completely out of danger from flooding. Events of hydrometeorological origin over the last 25 years has reminded man that the hydraulic infrastructures in place for a few centuries now, are not unalterable. An unmanaged vegetal colonization along the edge of watercourses (protection dikes, retention dams, appointed river banks, ect...) can present three types of inconvenience as (i) overflow in the case of watercourse containment, (ii) formation of woody jams which generate a risk of bridge obstructions or water retention, (iii) the presence of trees and their roots which damages the containment systems protecting the territories. It is important to manage the development of this vegetation in order to conserve the positive effects on the area while also limiting the negative impacts. The current boom in vegetation engineering techniques shows that man is relearning how to live as a "team" with nature.
\end{abstract}

\section{Background}

Historically, man lived in harmony with watercourses, cultivating their land and managing their habitat according to the benefits and the whims of the rivers (Fig. 1.a, b, c).

Since the end of the 19th century, man has domesticated with determination his environment (Fig 1.d). The rural exodus, the agricultural depreciation and river disturbance have resulted in a dynamic of closure areas and in the modification of hydraulic conditions during the flow of flood waters [1]. In parallel, civil engineering has strongly progressed in the domain of hydraulic structures but especially the construction of dams and dikes has also massively increased (Fig 1. e, f), part of the population has lost the culture of risk by thinking they were completely out of danger from flooding [2]. Events of hydrometeorological origin over the last 25 years has reminded man that the hydraulic infrastructures in place for a few centuries now, are not unalterable. More than $70 \%$ of these structure ruptures are linked to premature aging generating their failures, of which $20 \%$ ascribe to factors of external degradation such as burrowing animals or woody vegetation [3].

Riparian vegetation brings a lot of ecological functions along the rivers [4]. But an unmanaged vegetal colonization along watercourses can present different types of inconveniences [5, 6].

\footnotetext{
a Corresponding author: c.zanetti@arbeausolutions.fr
}

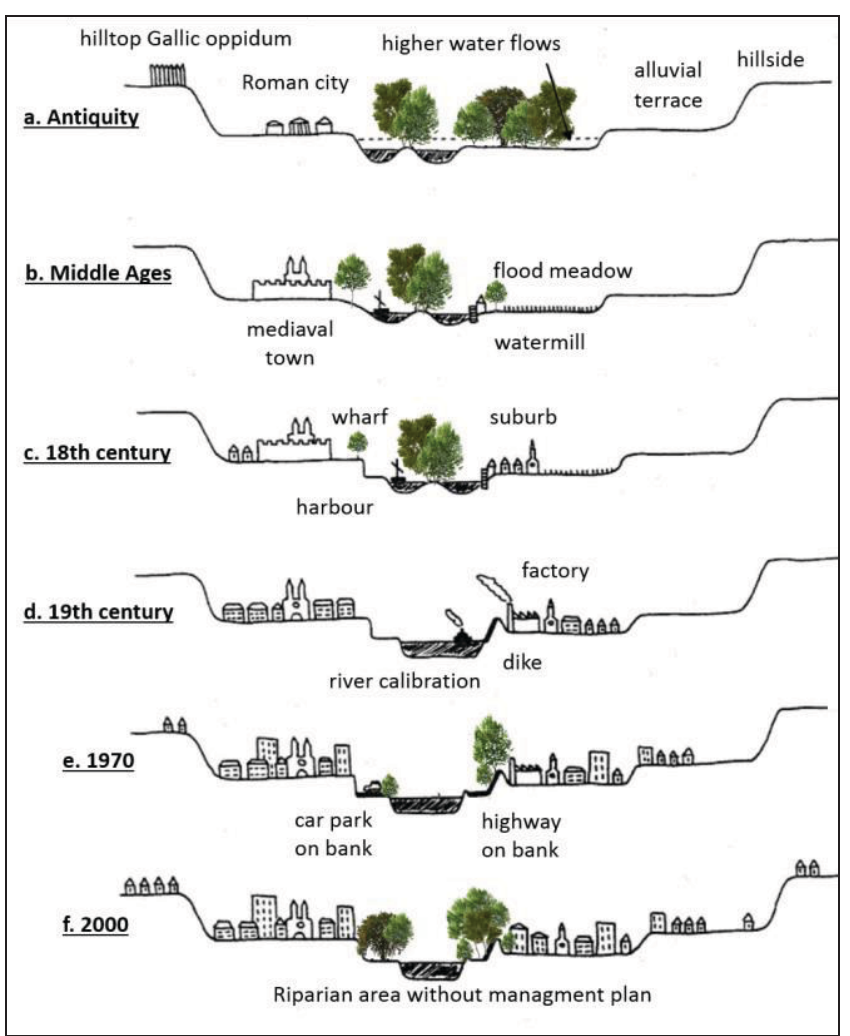

Figure 1. Flood plain transformation and vegetation evolution since Antiquity until today (Ph. Valette, modifié CZ) 
The figure 1 shows vegetation place along river since Antiquity. From the $19^{\text {th }}$ century, human activities pressured rivers and riparian environments and all vegetation has disappeared on river bank in a lot of the towns. After the second world war, with the advent of electricity, the intensive consumption of wood was reduced. As a result, woody vegetation reappeared along the rivers and started to grow on dikes. Nowadays, some river beds are completely invaded by vegetation.

\section{Vegetation benefits along rivers}

Riparian vegetation brings alot of ecological and landscaping functions along rivers and wetlands (Fig. 2). Dikes and river banks offer favourable conditions for vegetation growth. Vegetation along rivers and canals provides many ecological and social services in terms of terrestrial and aquatic biodiversity [7], erosion control [8, 9], slope stabilization [10, 11], water and landscape quality as well as leisure activities (Table 1).

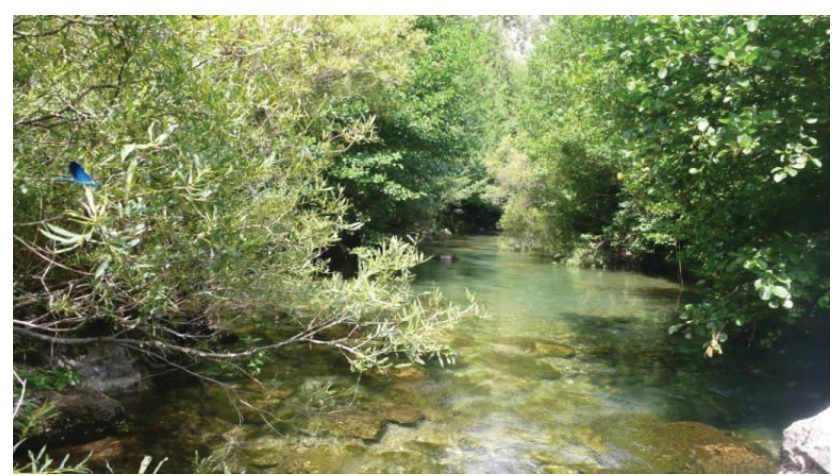

Figure 2. Riparian vegetation ecosystem (Source: www.aviador.gobage.net)

\begin{tabular}{|c|}
\hline $\begin{array}{c}\text { Ecological and landscaping } \\
\text { functions }\end{array}$ \\
\hline $\begin{array}{c}\text { Balancing temperature conditions in } \\
\text { near-ground layers of air and in the } \\
\text { soil }\end{array}$ \\
\hline $\begin{array}{c}\text { Shading avoids water temperature } \\
\text { increase in summer and eutrophication } \\
\text { process }\end{array}$ \\
\hline $\begin{array}{c}\text { Buffer zone and water } \\
\text { decontamination }\end{array}$ \\
\hline $\begin{array}{c}\text { Soil protection by interception of } \\
\text { rainfall }\end{array}$ \\
\hline $\begin{array}{c}\text { Soil reinforcement by roots and soil } \\
\text { drainage }\end{array}$ \\
\hline $\begin{array}{c}\text { Habitat for fauna and flora, wildlife } \\
\text { corridor and feeding reserve }\end{array}$ \\
\hline Noise and wind protection \\
\hline $\begin{array}{c}\text { Emphasis of the landscape by } \\
\text { variation of vegetation features and } \\
\text { colors }\end{array}$ \\
\hline Table 1. Riparian vegetation functions
\end{tabular}

Table 1. Riparian vegetation functions

\subsection{Specific wealth of riparian vegetation}

Riparian fauna communities vary both lengthwise and laterally along rivers such avifauna, fish fauna, mammals, insects, etc [12]. Often there are protected species in Natura 2000 sites and we can find endemic species such as mammals, birds, reptiles, insects, amphibians... Riparian vegetation provides an important feeding reserve and many hiding places for the fauna. For example, many chiropteran species can hide in woodpecker holes, below barks or in wood cracks and they need woody corridor for their movement [13]. In this way, riparian vegetation presents an important wildlife corridor for hunting. It also constitutes a great sheltered environment particularly during breeding season (Fig.3).

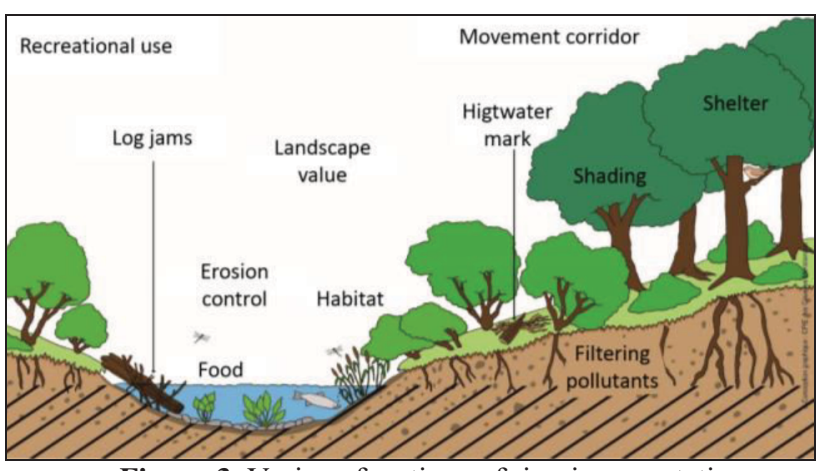

Figure 3. Various functions of riparian vegetation (Source : www.lodevoisetlarzac.fr)

The great wealth of riparian vegetation with lots of different species (trees, shrubs and herbaceous) increase the present wildlife population and decrease the risk of spreading diseases. For example, on Canal du Midi with only plane tree corridor (platanus. $s p$ ), the development of canker stain disease has been seen causing trees mortality along the canal (Fig.4).

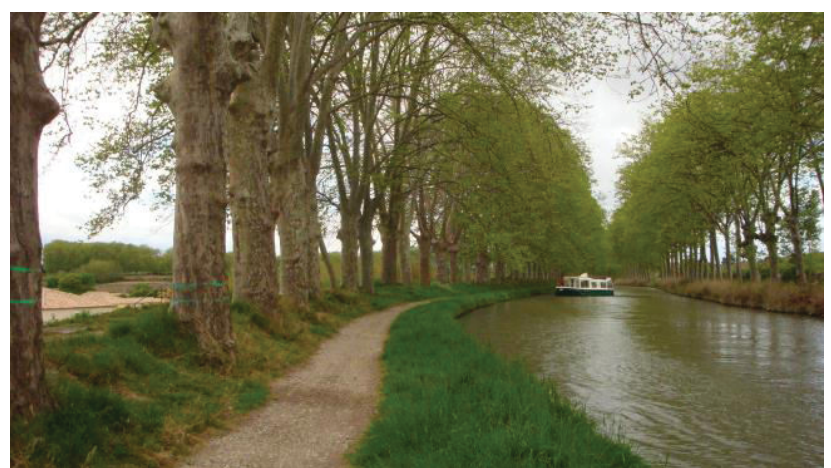

Figure 4. Plane trees infected by canker along Canal du Midi (Source : CZ)

For example, shady trees reduce the water temperature in summer thus protect fishes against bacteria. Moreover, without this native vegetation development, the trophic chain could be weakened, lots of species could be endangered of disappearing and could make place for invasive species like Japanese knotweed (Fallopia japonica) [14]. During winter these invasive species leaves bare banks with high risk of erosion (Fig.5) 


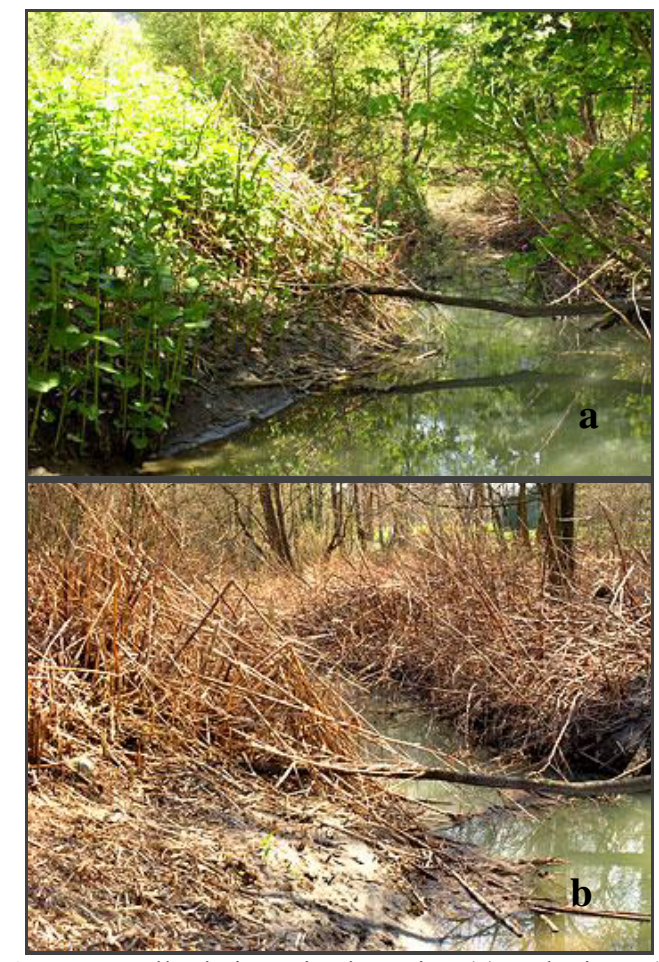

Figure 5. Fallopia japonica in spring (a) and winter (b) (Source:energie-environnement.ch)

\subsection{Riparian vegetation as protection}

As previously stated, riparian forest has an important function for keeping the native biodiversity of this place but is not the only function. Indeed, tree root systems have a real role of soil stabilisation and reduce sediment input in stream. On the contrary, a bare soil is easier erodible because of water erosion with impact of raindrop and gully erosion $[8,9]$.

On seashore, vegetation protects coastlines from erosion due to waves. For example, on river bank, roots reinforce sand dunes and improve resistance against wind and tides. On tropical area, mangrove trees and their roots systems significantly stabilize board coasts (Fig.6).

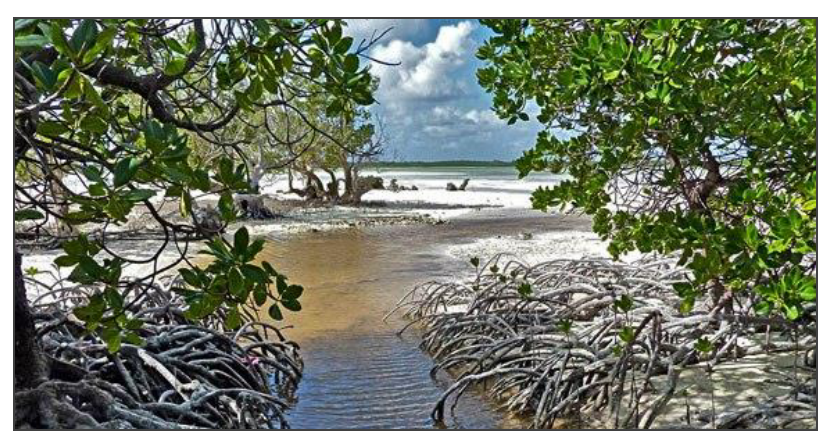

Figure 6: Effect of mangrove roots on soil stabilization near tropical coastline (Source: www.meridianes.org)

Furthermore, when agricultural lands borders rivers, the riparian vegetation represents a great buffer zone. The flow of many agricultural-derived contaminants like nitrates, phosphorus, farm effluents, phytosanitary products and pesticides can be reduced by the riparian vegetation and alluvial forest [15]. Riparian areas can modify, dilute or downgrade substances before the agricultural waters return to rivers (Fig. 7). This use of the riparian vegetation is also a good tool for ecosystem rehabilitation, managing both rivers and water-flows against eutrophication and pollution [16].

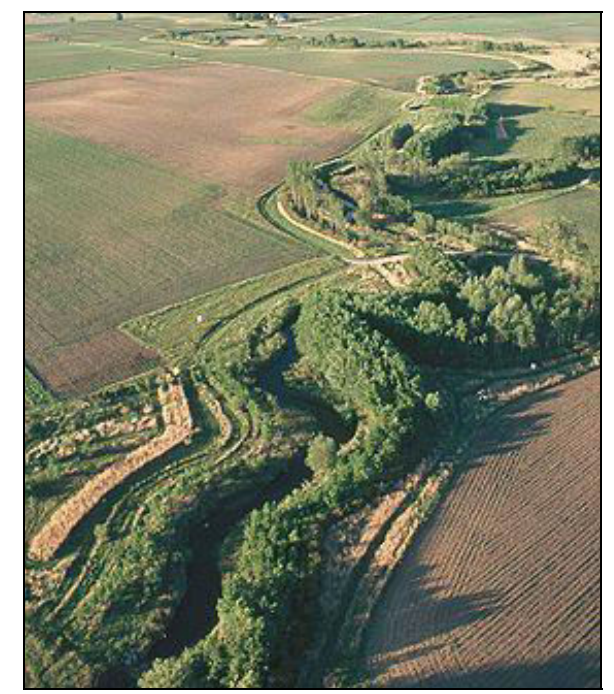

Figure 7. Ecological corridor as buffer zone (Source: www.ia.nrcs.usda.gov/news/successstories/)

\subsection{Landscape issues}

Forest layer provides an efficient protection against strong winds and noise nuisances from road traffic and other urban activities. In this way, the riparian vegetation area with pedestrian walkway and cycling lanes attracts many people. The landscape stake has lots of virtues on the health, life quality and well-being of users (Fig. 8).

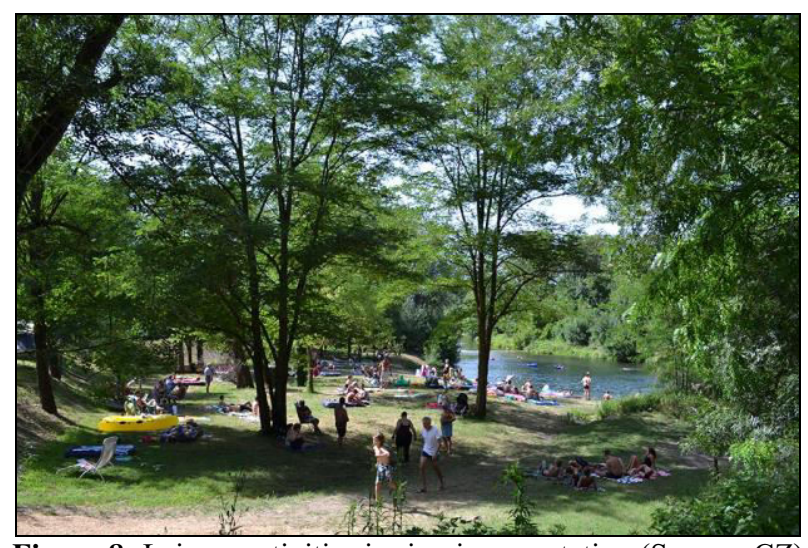

Figure 8: Leisure activities in riparian vegetation (Source: $\mathrm{CZ}$ )

\section{Vegetation inconvenient along rivers}

But despite all the benefits of riparian vegetation, an unmanaged vegetal colonization along rivers can present different types of inconveniences.

\subsection{Slow down floodwater flows}

In watercourses invaded by vegetation, the flow speed of floodwaters is slowed down and the rising of water levels can lead locally to an increase in the flooded 
surface area (Fig.9) or to an overflow in the case of watercourse containment (Fig.10).

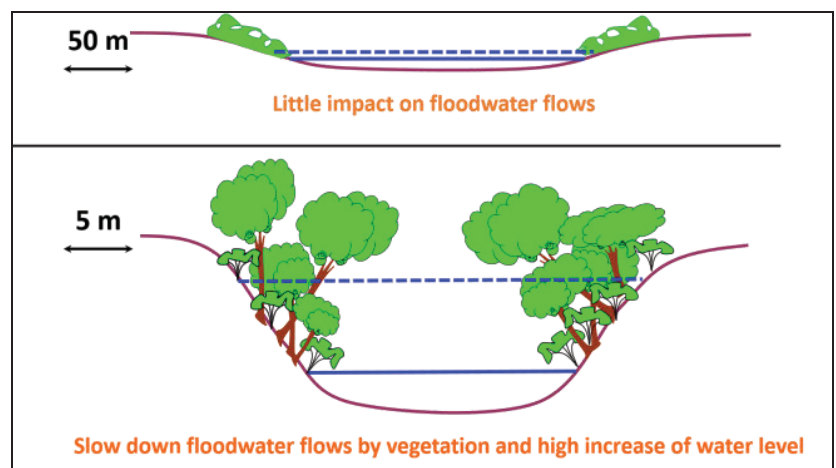

Figure 9. Vegetation and floodwater flows (Source :MV)

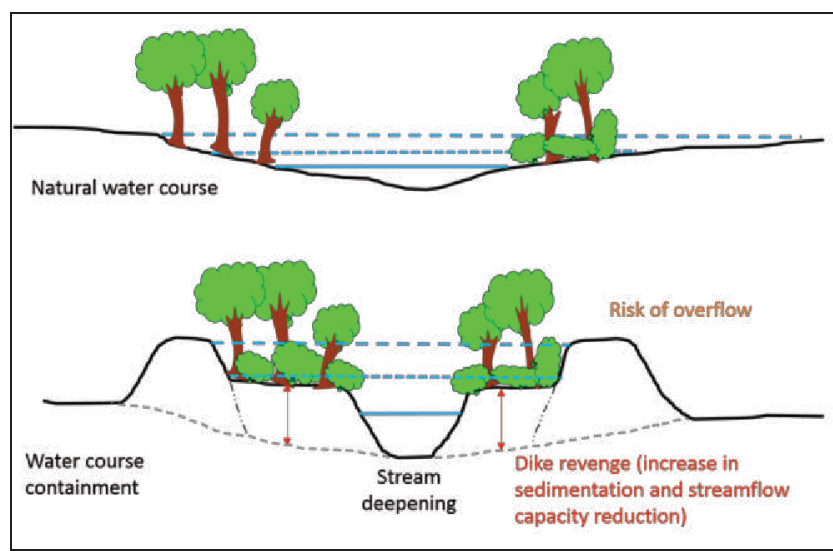

Figure 10. Revenge of the dike: reduction of streamflow capacity (Source: CZ)

\subsection{Log-jams risk on river}

During flood when vegetation has not been managed, rivers carry a high volume of dead wood. The abundant senescent vegetation along watercourses favours the formation of woody jams which generate a risk of water retention or bridges obstruction. In the latter case, flood water can overflow the top of the bridge (Fig.11).

Log-jams rupture can worsen flooding risk, with dangerous fast flowing water.

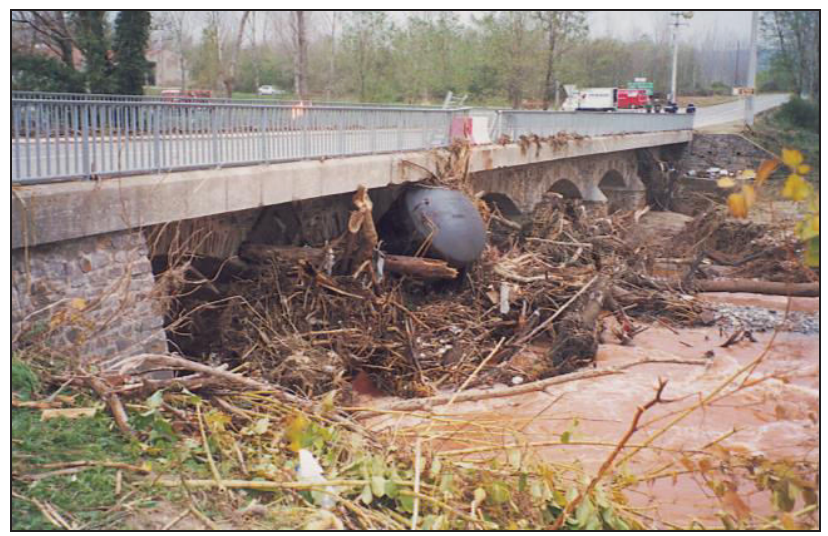

Figure 11. Bridge obstruction by log-jams

(Source: www.aquadoc.fr -1999 flood on Thoré river)

\subsection{Risk linked to vegetation on earth dikes and dams}

Earth dikes constitute a dense network in many territories with major human and economic stakes.

Woody vegetation induces several risks which are not compatible with dike safety and tree root systems generate a premature aging of embankments [17].

Unmanaged vegetation development on earth dikes and dams induces a low visibility and may mask disorders. As seen previously, these wooded areas attract a multitude of wild fauna such as burrowing animals causing underground galleries and holes which impact the permeability and stability of dikes (Fig.12).

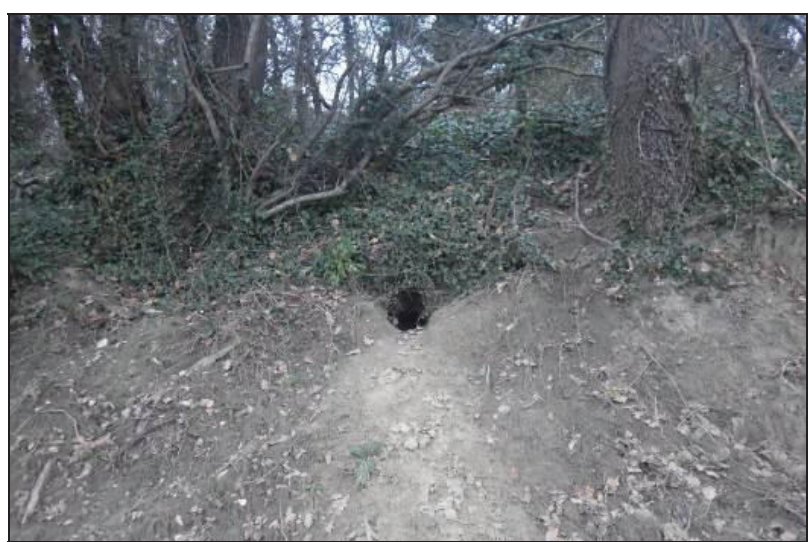

Figure 12. Badger's burrow in dike (Source: $\mathrm{CZ}$ )

In addition, the presence of trees and their roots damages the containment systems protecting the territories. In fact, root systems of most of the trees like locust (Robinia pseudiacacia), willow (salix.sp) and poplar (populous.sp) have some big and long horizontal roots which can penetrate the dike body. Poplar and willow also have big and long taproots which can grow deeply in the dike.

Most of the damages on hydraulic structures are mainly due to erosion phenomena which could be ranked in two types: internal and external erosion.

- External risk is linked to live roots (decompacting soil, cracking concrete, soil uprising). A dike is weakened by tree uprooting (Fig.13), an important part of the dike can be removed with root system.

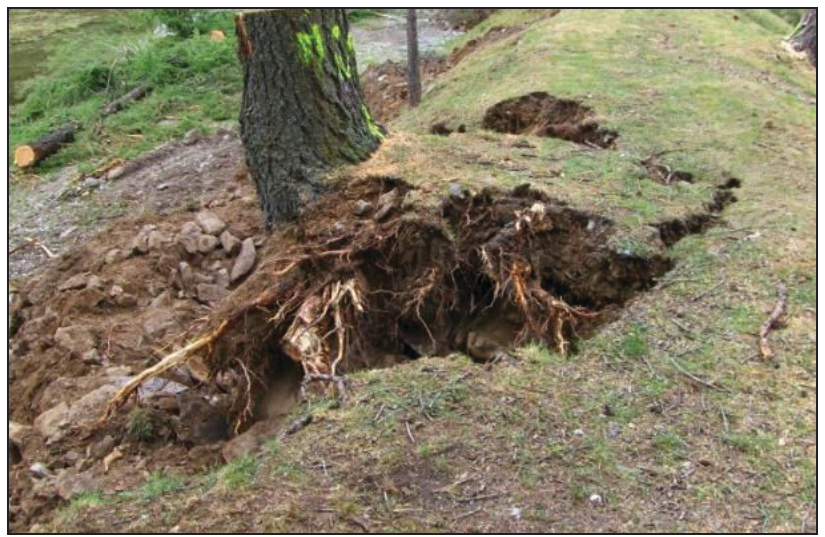

Figure 13. Dike degradation due to a falling pine tree (Source: CZ) 
- Internal erosion is mostly caused by decayed roots.

There is a high risk of piping due to root decay inside the dike and sinkholes creation with stumps decomposition (Fig.14).

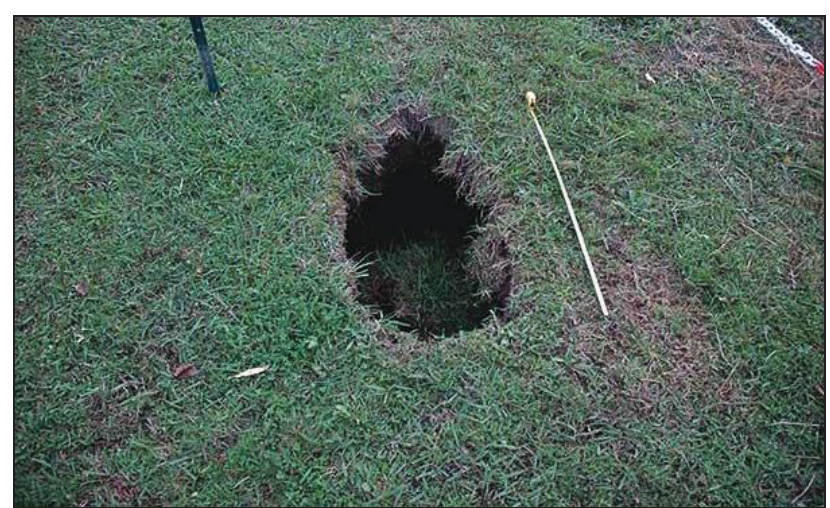

Figure 14. Sinkhole induced by stump decomposition and generating risk of internal erosion (Source: PM)

Internal erosion risk is also due to live roots penetrating rigid protection, like stone facing riprap (Fig.15) or concrete slab joints. During flood, water can infiltrate the embankment.

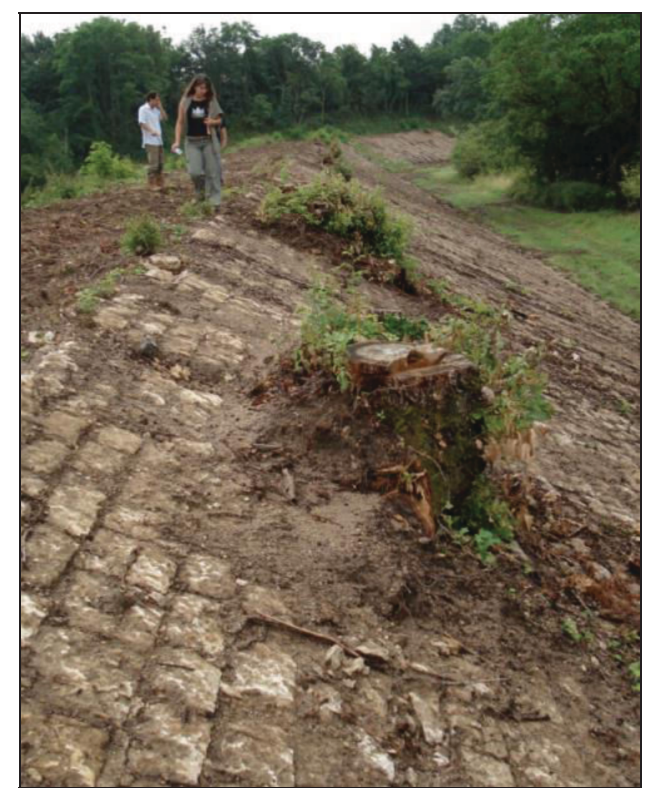

Figure 15. Stump development inside a handmade stone protection (source: PM)

To synthetize, vegetation on dikes increases risks of degradation which can be the origin of dangerous flood by dike breaching. Risks linked to vegetation are higher when human infrastructures (bridges, dams, dikes) are numerous.

\section{Case study: Isère riparian forest}

The Isere is an Alpine river in the Rhône-Alpes region of southeastern France. The Isère's course measures 286 kilometers and runs through a wide variety of landscapes. From its source near the Italian border in the western Alps, it crosses the Pays de Savoie and the Tarentaise Valley. Then it cuts between the Chartreuse and
Belledonne mountain ranges, follows the Vercors Massif, passes through the Dauphiné province and finally meets with the Rhône at the foot of the Vivarais.

Isere river crosses Grenoble city. This town is located in a depression and is confronted by air pollution problems and flood risk. The Isere river is almost completely contained by dikes.

The vegetation control and management on this site must take into account many contradictory social pressures and technical issues [17].

Ten years ago, Isère dikes were totally covered by trees (Fig. 16).

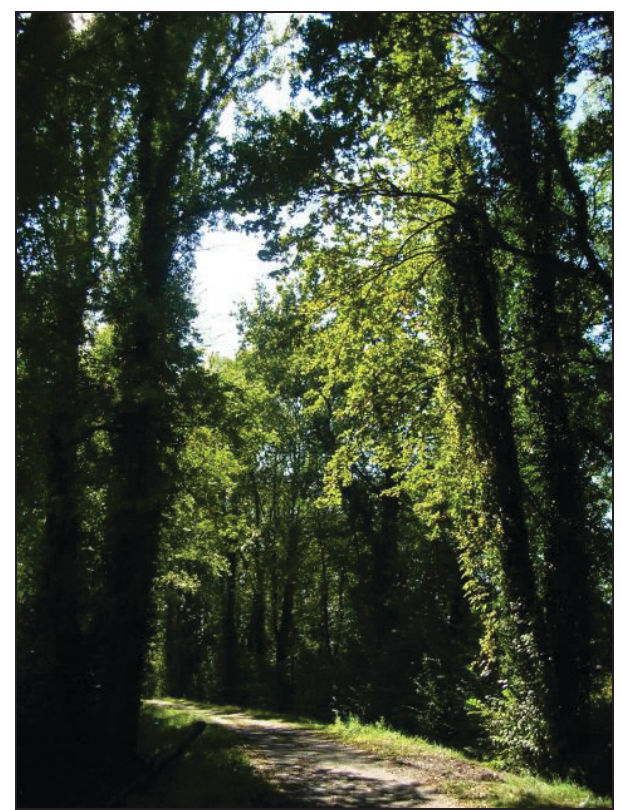

Figure 16. Forest on Isère dike near Grenoble, 10 years ago

Grenoble's dikes protect a lot of stakes; the population, university areas, industrial sites (sensitive factory classified "Seveso"). Dikes conditions, extremely wooded, induced a high level of risk and was not compatible with safety human and economic stakes. A management plan was elaborated and applied since 2003 to restore dikes condition. This plan allows to preserve protected species (Typha minima, Allium scorodoprasum, Castor.sp) and to eradicate invasive species (Fallopia japonica). After 10 years, $220 \mathrm{~km}$ of dikes were managed (20 km per year). Sometimes vegetation engineering techniques are used on river banks in order to stabilize soil to support the dike [18]. In this case the objective of safety and riparian environment conciliation was reached (Fig.17). On the concave bank, vegetation is kept clear to conserve dike control while on convex bank, riparian vegetation is kept natural and left to preserve biodiversity and habitats. 


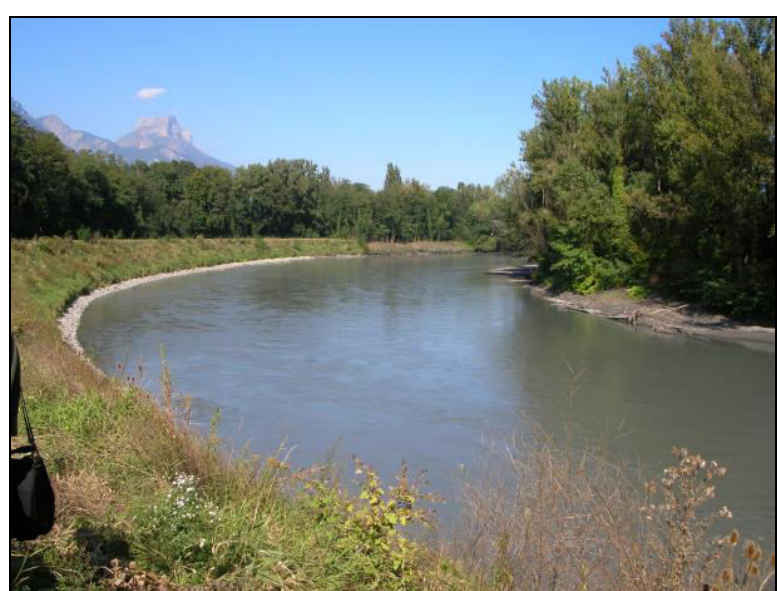

Figure 17. Result of conciliation between safety and riparian stakes between concave and convex banks (Source: CZ)

\section{Conclusion}

It is therefore important to manage the development of riparian vegetation in order to conserve the positive effects on the area (shade, water decontamination, bank stabilization, biodiversity) while also limiting the negative impacts.

The current boom in vegetation engineering techniques shows that man is progressively relearning how to live as a "team" with nature.

\section{References}

1. Toone, J., Rice S.P., Piégay, H. (2012). Spatial discontinuity and temporal evolution of channel morphology along a mixed bedrock-alluvial river: contingent responses to external and internal controls, Geomorphology

2. Valette P, Evolution spatio-temporelle de la forêt alluviale de la Garonne (2007), in Andrée Corvol, L'eau et la forêt (XIIIe -XXIe siècle), L'Harmattan, actes du colloque de Bordeaux, pp 301-322.

3. Haselsteiner R., Strobel T., (2007), Zum Einfluss von Bewuchs und Hohlraumen auf die durchsickerung. Techniche Universitat Munchen, Lehrstuhl und versuchsanstalt fur wasserbau und wasserwirtschaft.

4. Piégay H., Pautou G., Ruffinoni C., (2003) Les forêts riveraines des cours d'eau : écologie, fonctions, gestion, Institut pour le Développement Forestier, Paris. 464 p.

5. Vennetier M., Zanetti C, Meriaux P, Mary B (2014) Tree root architecture: new insights from a comprehensive study on dikes, Plant and Soil, 2014, DOI 10.1007/s11104-014-2272-9.

6. Zanetti C, Vennetier M, Mériaux P, Provansal M (2014) Plasticity of tree root system structure in contrasting soil materials and environmental conditions, Plant and Soil, 2014, DOI 10.1007/s11104-014-2253-z.

7. Tabacchi, E., D. Correll, R. Hauer, G. Pinay, A. Planty-Tabacchi, and R. Wissmar, (1998) Development, maintenance and role of riparian vegetation in the river landscape. Freshwater Biol, 40. p. 497-516.

8. Abernethy, B. and I.D. Rutherfurd, (2001), The distribution and strength of riparian tree roots in relation to riverbank reinforcement. Hydrol Process, 15. p. 36-79.

9. Pollen, N. (2007), Temporal and spatial variability in root reinforcement of streambanks: Accounting for soil shear strength and moisture. Catena, 69. p. 197205.

10. Danjon, F., D.H. Barker, M. Drexhage, and A. Stokes, (2008), Using Three-dimensional Plant Root Architecture in Models of Shallow-slope Stability. Annals Bot, 101. p. 1281-1293.

11. Nilaweera, N. and P. Nutalaya, (1999), Role of tree roots in slope stabilisation. Bull engineer geol environ, 57. p. 337-342.

12. Decamps H., (2003), Ripisylves : la biodiversité par l'instabilité, Fôret Méditerranéene, tome 24, n³, p. 221-230.

13. Grindal S. D., J. L. Morissette, et R. M. Brigham, (1999), Concentration of bat activity in riparian habitats over an elevational gradient, Can. J. Zool., vol. 77, no 6, p. 972-977.

14. Gerber E., C. Krebs, C. Murrell, M. Moretti, R. Rocklin, et U. Schaffner, (2008), Exotic invasive knotweeds (Fallopia spp.) negatively affect native plant and invertebrate assemblages in European riparian habitats, Biol. Conserv., vol. 141, $\mathrm{n}^{\circ} 3$, p. 646-654.

15. Grimald, C., Baudry, J., Pinay, G., (2012), Des zones tampons dans les paysages ruraux pour la régulation de la pollution diffuse, Innovation Agronomiques, 23, p 55-68.

16. Osborne LL. et DA. Kovacic, (1993), Riparian vegetated buffer strips in water-quality restoration and stream management, Freshw. Biol., vol. 29, no 2, p. 243-258.

17. Venntier M, Mériaux P., Zanetti C, (2015) Gestion de la végétation des ouvrages hydrauliques en remblai, Cardère éditeur, Irstea Aix en Pce, 232p.

18. Bonnin L, Evette A, Frossard PA, Prunier P, Roman D, Valé N (2013) Génie Végétal en rivière de montagne, Guide technique, Interreg France-Suisse, $318 \mathrm{p}$. 